\title{
SOME OBSERVATIONS ON THE BACTERIOLOGICAL INDEX IN LEPROSY
}

by S. G. BrownE, M.D., F.R.C.S., M.R.C.P., D.T.M.

Superintendent, Yalisombo Leprosarium, Belgian Congo

In reviewing a series of cases of "open" leprosy (lepromatous and dimorphous) that had become bacteriologically negative to standard methods of examination and had remained so for several consecutive examinations, the opportunity was taken of analyzing the former persistence of $M y(0)$. leprae at the various sites from which material had been taken regularly by the scraped incision method. One of the objects in view was to assess the value of routine methods of examination that could be adopted widely in a domiciliary leprosy service treating great numbers of patients and using auxiliary medical personnel.

The sites from which smears were taken were the following:

No. 1. Ear-lobe;

2. Forehead;

3. Cheek;

4. Most clinically active part of the edge of a lesion;

5. Apparently healthy skin;

6. Nasal mucosa;

as advocated by Zanetti (1947) and by Browne (1955).

The dermal smears were stained by Ziehl-Neelsen's method, and the degree of infection at each site recorded on Dharmendra's notation (Cochrane, 1952):

1. Slight. Bacilli in occasional fields, not more than 2 or 3 per field; 1 or 2 small globi in 50 fields;

2. Moderate. Bacilli in every field, but not more than 10 per field; a few globi here and there:

3. Heavy. Numerous bacilli and globi in every field;

4. Massive. Innumerable bacilli, and large numbers of globi, in every field.

The "bacteriological index" is the average of the indexes at each of the six sites.

It is conceded that the methods of obtaining the material for staining, and of determining the index at each of the sites, are not of absolute value; but with standard procedures applied uniformly, the method has proved satisfactory (Hanks, 1956).

For the appraisal of the conclusions reached in the course of the present enquiry, the following figures are given of the endemicity of leprosy in the district from which most of the cases under review came: 


\begin{tabular}{l|c|c|c} 
& $\begin{array}{c}\text { Total } \\
\text { population }\end{array}$ & $\begin{array}{c}\text { Cases of leprosy } \\
\text { Number }\end{array}$ & $\begin{array}{c}\text { under treatment } \\
\%\end{array}$ \\
\cline { 2 - 3 } Men & 14,750 & 2163 & 14.67 \\
Women & 12,255 & 1921 & 15.68 \\
Children & 18,030 & 1265 & 7.02 \\
\cline { 2 - 3 } & 45,035 & 5349 & 11.88
\end{tabular}

The clinical forms of leprosy were classified as follows:

\begin{tabular}{lll|c|r}
\multicolumn{2}{c|}{ Form } & & $\begin{array}{c}\text { Number } \\
\text { of cases }\end{array}$ & \multicolumn{1}{c}{$\%$} \\
\hline Tuberculoid & $\ldots$ & $\ldots$ & 3889 & 72.71 \\
Indeterminate & $\ldots$ & $\ldots$ & 187 & 3.49 \\
Lepromatous & $\ldots$ & $\ldots$ & 1104 & 20.68 \\
Dimorphous & $\ldots$ &. & 169 & 3.16 \\
& & & 5349 & 100.00
\end{tabular}

N.B.-These figures take no account of the number of cases of tuberculoid leprosy regarded as quiescent and not needing treatment, either from spontaneous regression or after adequate sulphone therapy; thus the numbers and percentage of tuberculoid cases should be higher than that indicated.

The cases that form the subject of this enquiry were inpatients at the Yalisombo Leprosarium in the Oriental Province of the Belgian Congo, and comprised 156 lepromatous cases and 34 dimorphous cases; they represent a typical cross-section of the members of these groups under treatment throughout the district.

These patients had received treatment as follows:

\section{Lepromatous Cases:}

Cases

1. Dapsone tablets orally, with incorporated protoxalate of $\begin{array}{lllllllll}\text { iron } & \ldots & \ldots & \ldots & \ldots & \ldots & \ldots & \ldots & 106\end{array}$

2. Dapsone by intramuscular injection of a $25 \%$ suspension in chaulmoogra oil $\quad \ldots \quad \ldots . \quad \ldots \quad$. .

3. Dapsone orally, interspersed with series of weekly or twice-weekly intramuscular injections of $50 \%$ aqueous sulphetrone (with $0.5 \%$ phenol) $\quad \ldots \quad \ldots \quad \ldots 35$

4. Sulphetrone by intramuscular injection, alone .. $\quad \ldots \quad 8$

5. Sulfon-Cilag orally (a mono-substituted sulphone: Browne, 1955), followed by dapsone orally. . . . 4 


\section{Dimorphous cases:}

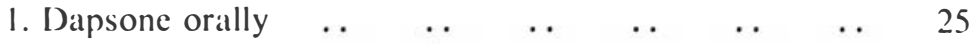

2. Sulphetrone by injection, alternating with dapsone orally 9

In conformity with the general experience of leprosy in the Bantu, the incidence of lepra reaction during the course of treatment was low.

\section{Original bacteriological index on admission}

Most cases had received no treatment before admission, and the index represents the findings at the first examination (which coincided with the first clinical examination):

Bacteriological index

Site Lepromatous Dimorphous

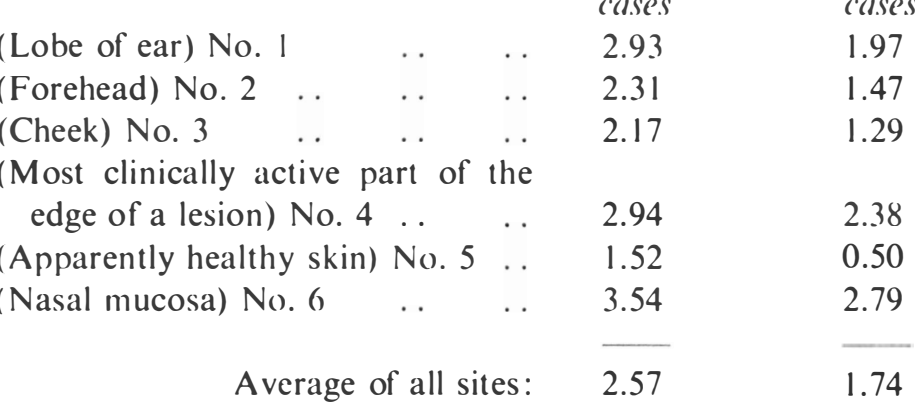

At each site, the average index was lower in the dimorphous group than in the lepromatous; but in both groups the average index showed the same relation between site and site, i.e., the highest index was in site No. 6 and the lowest in site No. 5, and correspondingly. The nasal mucosa was consistently the most highly positive site, containing many globi in each field of the oil-immersion lens in 130 out of 156 lepromatous cases, and in 18 out of the 34 dimorphous cases; and a few globi in 50 fields in a further 14 lepromatous cases, and 10 dimorphous cases.

The material from the earlobes was more highly positive in the lepromatous cases than in the dimorphous cases: $67 \%$, as against $35 \%$, had numerous globi at this site.

Apparently normal skin was highly positive in 43 lepromatous cases $(28 \%)$, and in 3 dimorphous cases $(9 \%)$.

\section{Sites first becoming positive}

The records furnish no evidence concerning the site that first becomes bacteriologically positive, since most patients had more than one site - usually several-positive at the first examination. In one case site No. 6, and in two cases site No. 4, were initially the only sites positive. 
In some catses, the initial indexes for some sites were much higher than those of the other sites. This may or may not imply that these sites were the first to become bacteriologically positive in those patients; other factors, such as intensity of the infection, the disposition of Myco. leproce in the nasal mucosa or elsewhere, and the cellular pattern of the epidermis-are all involved.

With this proviso, it is of interest to note that Site No. I had the highest initial index in 6 cases; site No. 2 in 1 case; site No. 3 in 1 case; site No. 4 in 8 cases; site No. 5 in no calse; and site No. 6 in 14 calses.

\section{Time elapsing before bacterial negativity was achieved}

The following ligures refer only to those patients whose index had become zero before the date of the present encuiry, and take no account of those who were still bacteriologically positive after at least four years of controlled treatment.

\section{L.epromatous cases}

\begin{tabular}{|c|c|c|}
\hline $\begin{array}{l}\text { Clinical } \\
\text { stage }\end{array}$ & $\begin{array}{c}\text { Number o) } \\
\text { cases }\end{array}$ & $\begin{array}{l}\text { Average duration of } \\
\text { treatment before } \\
\text { hacterial negativity }\end{array}$ \\
\hline $\begin{array}{r}\text { I } \\
\text { II } \\
\text { III }\end{array}$ & $\begin{array}{r}8 \\
45 \\
103\end{array}$ & $\begin{array}{l}2.68 \text { years } \\
2.10 \\
2.31\end{array}$ \\
\hline \multicolumn{2}{|c|}{ All stages: 156} & 2.26 years \\
\hline
\end{tabular}

N.B.--The "clinical stage" indicates in the main the extent of skin involvement in each case.

Another analysis based on the initial bacteriological index, gives the following results:

\begin{tabular}{l|c|c}
$\begin{array}{c}\text { Initial } \\
\text { hacteriological } \\
\text { index }\end{array}$ & $\begin{array}{c}\text { Number of } \\
\text { cases }\end{array}$ & $\begin{array}{c}\text { Average duration of } \\
\text { treatment hefore } \\
\text { hacterial negativity }\end{array}$ \\
\hline 3.0 and over & 60 & 2.42 years \\
2.0 to 2.9 & 48 & 2.42 \\
1.0 to 1.9 & 39 & 1.83 \\
under 1.0 & 9 & 2.15 \\
\hline All cases & 156 & 2.26 years
\end{tabular}

\section{Dimorphous cases}

The classification of dimorphous cases into clinical groupings in accordance with the extent of the involvement of the skin was not considered practicable in view of the nature of the lesions and the 
discordance between the extent of the lesions and the gravity of the case. Analysis based on the objective standard of the bacteriological index revealed the following:

\begin{tabular}{c|c|c}
$\begin{array}{c}\text { Initial } \\
\text { hacteriological } \\
\text { index }\end{array}$ & $\begin{array}{c}\text { Number of } \\
\text { cases }\end{array}$ & $\begin{array}{c}\text { Average duration } \\
\text { of ireatment hefore } \\
\text { hacterial negativity }\end{array}$ \\
\hline 3.0 and over & 5 & 2.05 years \\
2.0 to 2.9 & 9 & 1.87 \\
1.0 to 1.9 & 12 & 1.29 \\
under 1.0 & 8 & 1.68 \\
\hline All cases & 34 & 1.65 years
\end{tabular}

Order in which the sites become bacteriologically negative

This order was identical in the lepromatous and dimorphous groups, and was in strictly inverse relation to the degree of initial bacterial positivity of the different sites, i.e., the site with the lowest initial index became bacteriologically negative first, and vice versa; this was the order:

Site No. 5. Apparently healthy skin:

3. Cheek:

2. Forehead;

1. Ear-lobe;

4. Active edge of lesion:

6. Nasal mucosa.

Time elapsing before sites become bacteriologically negative

\begin{tabular}{c|c|c} 
& $\begin{array}{c}\text { Lepromatous } \\
\text { colses }\end{array}$ & $\begin{array}{c}\text { Dimorphous } \\
\text { colses }\end{array}$ \\
\cline { 2 - 3 } Site No. 5. & 0.70 years & 0.21 years \\
3. & 1.20 & 0.64 \\
2. & 1.38 & 0.90 \\
1. & 1.85 & 1.06 \\
4. & 1.94 & 1.60 \\
6. & 2.26 & 1.65
\end{tabular}

Last site to become bacteriologically negative

$\mathrm{It}$ is of clinical interest, practical value, and epidemiological importance to recognize that $M_{y}$ 'co. leprae may be disseminated from various cutaneous surfaces after apparent clinical cure, and, further, to know that a single negative bacteriological examination (by standard methods) of smears from one site does not necessarily indicate that the patient is now non-infectious. Thus, after five sites had become negative, one site remained positive perhaps for many months; similarly, after four sites had become negative, two sites may remain positive for long periods. 


\begin{tabular}{|c|c|c|c|c|c|c|c|}
\hline \multirow[b]{2}{*}{ Site No. I } & \multicolumn{3}{|c|}{$\begin{array}{l}\text { Lepromatous Casts } \\
\text { Sitre's remaining positive: }\end{array}$} & \multicolumn{3}{|c|}{ 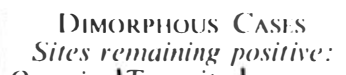 } & ToIAI \\
\hline & $\begin{array}{r}10 \\
4 \\
2 \\
16 \\
1 \\
51\end{array}$ & $\begin{array}{l}30 \\
11 \\
10 \\
42 \\
\frac{2}{4} \\
47\end{array}$ & $\begin{array}{r}40 \\
15 \\
12 \\
58 \\
3 \\
98\end{array}$ & $\begin{array}{l}1 \\
1 \\
1 \\
6 \\
0 \\
5\end{array}$ & $\begin{array}{r}4 \\
3 \\
2 \\
14 \\
0 \\
17\end{array}$ & $\begin{array}{r}5 \\
4 \\
3 \\
20 \\
0 \\
22\end{array}$ & $\begin{array}{r}45 \\
19 \\
15 \\
78 \\
3 \\
320\end{array}$ \\
\hline $\begin{array}{l}\text { Total sites } \\
\text { remaining } \\
\text { positive }\end{array}$ & 84 & 142 & 226 & 14 & 4) & 54 & 280 \\
\hline $\begin{array}{l}\text { Number of } \\
\text { pattients }\end{array}$ & 84 & 71 & 155 & 14 & 20) & 34 & 189 \\
\hline
\end{tabular}

(f) the 10 lepromatous eases in which Site No. I was the last site remaining positive, 8 were nodular cases; of the 30 lepromatous cases in which this site was one of the last two remaining positive, 16 were nodular cases.

The nasal mucosa was the site to remain positive longest in 51 out of 84 lepromatous cases-more frequently than the edge of the skin lesion, or the ear-lobe.

These three sites - the nasal mucosa, the edge of the lesion, and the ear-lobe-together account for 243 out of 280 sites last remaining bacteriologically positive.

\section{Infectivity of secretions from trophic ulcers}

The patients of these two groups who were suffering from trophic ulceration were included for statistical purposes in a larger group containing tuberculoid cases and "open" cases still bacteriologically positive.

Four lepromatous cases had on five occasions acid-fast bacilli in serious discharges from trophic ulcers; and four tuberculoid cases also had acid-fast bacilli on five occasions. A total of over 1,400 bacteriological examinations were performed in this series of serous discharges from 63 "open" (lepromatous and dimorphous) cases, and 45 tuberculoid cases.

\section{Conclusions}

Microscopic examination of material obtained by the scraped incision method from the nasal mucosa, the most active edge of a lesion, and of the ear-lobe (in that order), is of value for purposes of confirmation of the diagnosis of lepromatous and dimorphous leprosy, for assessment of response to treatment, and for ascertainment of freedom from infectivity. The discharge from trophic ulcers is a relatively unimportant source of infection.

\section{Acknowledgements}

My grateful thanks are due to Dr. R. G. Cochrane, F.R.C.P., for his helpful criticisms.

\section{References}

1. Browne, S. G. (1955) Internat. J. Leprosy 23, 284.

2. Cochrane, R. G. (1952) Leprosy Re'l. 23, 135.

3. HANks, J. H. (1956) Internat. J. Leprosy 24, 424. 